\title{
Seismic Response of Steel Braced Vertically Irregular RC Frame Considering Soil Structure Interaction
}

\author{
Basavanagowda G M, Raje Gowda, Prashanth Sunagar, Manish S D
}

\begin{abstract}
Bracing system is one of the structural system which forms an integral part of the frame. Steel bracings have been used extensively as a structural system to resist seismic loads in the recent times due to their passive energy dissipation property. Steel bracing being economical and easy to erect assists to enhance the strength and retrofitting properties of a structure and their effective performance in controlling seismic effects on the structures during earthquake. In the present study the effect of soil structure interaction (SSI) on multi-storied vertically irregular RC buildings on a horizontal soil profile with varying underlying soil types using concentric chevron bracing is investigated. A G+4 story vertically irregular building (with bracing and without bracing) is analyzed as per IS 1893:2002 using ANSYS.v19 software with fixed and flexible foundation. The soil structure interaction effects on the flexible foundation are analyzed and the effectiveness of the chevron braced frame on the seismic performance of the building is studied. Two different combination of the soil profile for the same building with bracing and without bracing and for free headed and fixed headed flexible foundation condition has been analyzed in response spectrum method for Winkler theory. The performance of the building is evaluated in terms of displacement, storey drift and bending moment along the pile and time period. It was found that the chevron bracing with fixed headed flexible foundation significantly contributes to the structural stiffness and reduces the displacement compared to the bare frame and also the SSI effect considering the water table showed more displacement when compared to the structure on saturated hard soils. Time period increases when SSI was considered.
\end{abstract}

Keywords: Soil Structure Interaction (SSI), Response Spectrum analysis, vertically irregular RC Building.

\section{INTRODUCTION}

From the past and recent earthquakes ,it is understood that the soil structure interaction (SSI) effects plays an important role in determining the response of the building structures.[1]

Manuscript published on January 30, 2020.

* Correspondence Author

Basavanagowda G M*, Assistant Professor in Department of Civil Engineering,, RIT, Bangalore.

Raje Gowda, Assistant professor in Department of Civil Engineering RIT, Bangalore.

Prashanth Sunagar, Assistant professor in Civil engineering department at Ramaiah Institute of Technology Bangalore.

Manish S D, Assistant professor in Civil engineering department at BMS Institute of Technology and Management, Bangalore.

(C) The Authors. Published by Blue Eyes Intelligence Engineering and Sciences Publication (BEIESP). This is an open access article under the CC-BY-NC-ND license

(http://creativecommons.org/licenses/by-nc-nd/4.0/)
The seismic excitation experienced by structure is a function of the earthquake source , travel path effects , local site effects and SSI effects. Soil structure interaction is a thriving areas of research in structural engineering. It can be defined as the coupling between a

structure and its supporting medium. SSI has shown that the dynamic response of a structure supported on flexible soil differs from those supported on rigid base [2]. Seismic response of a irregular building gives different performance compared to the regular structures, these maybe due to height irregularity due to sudden changes in the stiffness, strength and mass between two adjacent stories [3]. A multi-storied, multi-paneled frame is a complex statically indeterminate structure. It consists of a number of beams and columns built monolithically, forming a network. This building frame is subjected to both vertical as well as horizontal loads. The high rise structures are subjected to dominantly horizontal forces i.e., earthquake forces in addition to gravity forces. Therefore, it is warranted, to make the building earthquake resistant, to resist the effects of ground shaking without collapsing. Kotkar R.K et al (2017), [4] studied the effects of SSI on building with stiffness irregularity under seismic excitation using finite element method using SAP 2000 V18 software. Response spectrum analysis has been carried out and the parameters like time period, base shear, roof top displacement and storey drift of the building frame resting over soil media was studied. It was seen from the results that the base shear decreases for stiffness irregularity type of building whereas time period, top storey displacement and storey drift has increased and also it was known that these effects are more prominent in soft soil condition.

Thusoo et al.[5] studied the response of buildings with SSI with varying soil types Using ANSYS software, In which deflection in the structure considering SSI decreased when compared with the fixed base building and the time period while considering SSI increases when compared with fixed base Structure without considering SSI.

\section{OBJECTIVES OF THE STUDY}

The analysis of 4 storied RC chevron braced system with fixed base and flexible base having free head and fixed head with and without bracing condition with varying underlying soils considering SSI effects with and without water table has been performed and overall seismic evaluation of the structures were carried out using parameters like displacement, 
storey drift, bending moment along the pile, and time period obtained from the response spectrum analysis using the ANSYS v19 software for the cases given below:

\section{A. Fixed Base Analysis}

A four storied vertically irregular RC building was considered with and without bracing. Performance parameters like displacement and time period were obtained using Response Spectrum analysis from ANSYS v19 software.

\section{B. Soil Structure Interaction.}

The effect of soil structure interaction (SSI) on a multi-storied building on horizontal soil profile with varying underlying soil types using chevron steel bracing is investigated. Two different combinations of soil profile for the same building with and without bracing having free head and fixed head pile condition has been analyzed for Winkler theory.

\section{* Combination -I}

Free headed $\quad: 2 m$ clay $+3 m$ stiff clay $+3 m$ loose sand (saturated)

Fixed headed $\quad$ : $3 m$ clay $+3 m$ stiff clay $+3 m$ loose sand (saturated)

\section{* Combination -II}

Free headed $\quad$ : $2 m$ clay $+3 m$ loose sand (saturated) $+3 m$ stiff clay

Fixed headed $\quad$ : 3m clay $+3 m$ loose sand (saturated) $+3 m$ stiff clay

\section{STRUCTURAL DETAILS AND MATERIAL PROPERTIES}

Table 1: Soil Properties [6]

\begin{tabular}{|c|c|c|c|c|}
\hline Soil Type & $\begin{array}{c}\text { Unsaturated } \\
\text { Unit Weight } \\
{\left[\boldsymbol{\gamma}_{\text {sat }}\right]} \\
\mathbf{( k N / \mathbf { m } ^ { 3 } )}\end{array}$ & $\begin{array}{c}\text { Young's } \\
\text { Modulus } \\
{\left[\mathbf{E}_{\mathbf{s}}\right]} \\
\left(\mathbf{k N} / \mathbf{m}^{3}\right)\end{array}$ & $\begin{array}{c}\text { Poisson's } \\
\text { ratio } \\
{\left[\boldsymbol{\mu}_{\mathbf{s}}\right]}\end{array}$ & $\begin{array}{c}\text { Stiffness } \\
\text { of the } \\
\mathbf{s o i l}[\mathbf{k}]\end{array}$ \\
\hline $\mathbf{( k N / \mathbf { m } ^ { 3 } )}$
\end{tabular}

Table 2: Properties of RC Frame, Pile and Pile cap

\begin{tabular}{|c|c|}
\hline $\begin{array}{c}\text { Characteristics strength of } \\
\text { concrete [M25] }\end{array}$ & $25 \mathrm{~N} / \mathrm{mm}^{2}$ \\
\hline Young's Modulus[ $\left.\mathbf{E}_{\mathbf{s}}\right]$ & $25 \times 10^{6} \mathrm{kN} / \mathrm{m}^{2}$ \\
\hline Poisson's ratio[ $\boldsymbol{\mu}]$ & 0.2 \\
\hline Flexural rigidity [EI] & $13.02 \times 10^{4} \mathrm{kN} \mathrm{\textrm {m } ^ { 2 }}$ \\
\hline Weight per unit volume[w] & $25 \mathrm{kN} / \mathrm{m}^{3}$ \\
\hline Shear modulus[G] & $10.41 \times 10^{6} \mathrm{kN} / \mathrm{m}^{2}$ \\
\hline
\end{tabular}

Table 3: Structural details of the model

\begin{tabular}{|l|l|}
\hline \multirow{2}{*}{ Concrete Frame } & Columns $=400 \times 400 \mathrm{~mm}$ \\
\cline { 2 - 2 } & Beams $=300 \times 300 \mathrm{~mm}$ \\
\cline { 2 - 2 } & Slab $=150 \mathrm{~mm}$ \\
\hline Concrete Pile & Length of the Pile $=9 \mathrm{~m}$ \\
\cline { 2 - 2 } & Cross-Section $=0.4 \times 0.4$ \\
\hline Concrete Pile Cap & Length $=1.6 \mathrm{~m}$ \\
\cline { 2 - 2 } & Width $=1.6 \mathrm{~m}$ \\
\cline { 2 - 2 } & Depth $=350 \mathrm{~mm}$ \\
\hline Steel Bracing & ISA $200 \times 200 \times 12 \mathrm{~mm}$ \\
\hline Storey Height & $3 \mathrm{~m}$ \\
\hline Number of Bays & 2 Bays \\
\hline Bay Width & $5 \mathrm{~m}$ \\
\hline
\end{tabular}

\section{MODELLING AND ANALYSIS}

Firstly a four storied vertically irregular 2 bay RC building with and without bracing is analyzed using a fixed base without considering SSI. The effectiveness of the chevron braced frame on the seismic performance of the building is studied using ANSYS v19 as shown in the figure 2. Then the building is analyzed with flexible approach that is having spring based conditions, that is in relation with stiffness of the soil. Two different combination of soil profile for the same building with bracings, without bracing and for free headed and fixed headed condition has been analyzed for Winkler theory. Analysis is done with the Response spectrum analysis for seismic zone $\mathrm{v}$ calculating the spectral acceleration according to IS 1893: 2002. The earthquake response of the building frames considering the stiffness of the soil is examined and results are compared with fixed base condition. Analysis was carried out to find the displacement, storey drift, bending moment along the pile and time period of the structure. The graph showing spectral acceleration $\mathrm{v} / \mathrm{s}$ frequency is shown in the figure 1

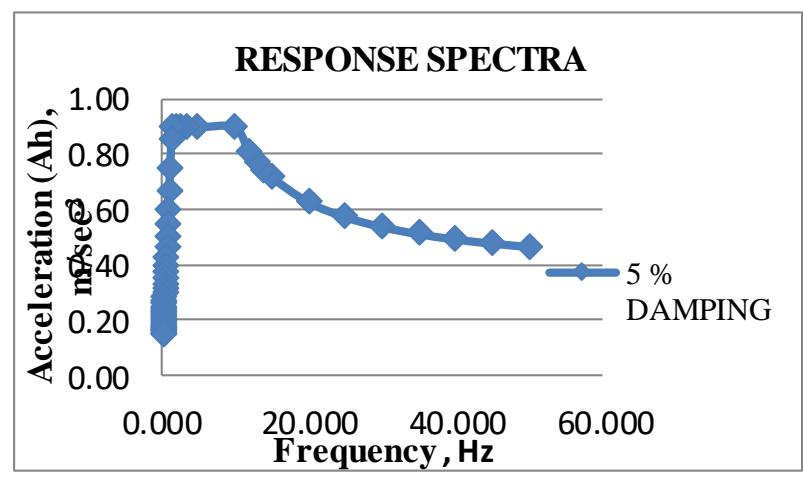

Fig. 1.Response Spectra for Soil type-III

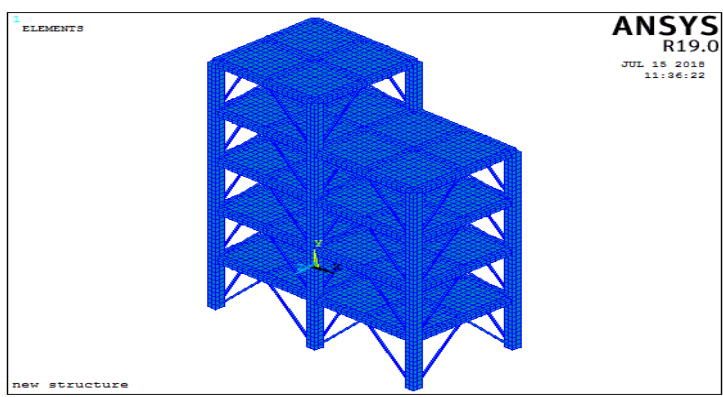

Published By:

Blue Eyes Intelligence Engineering \& Sciences Publication 


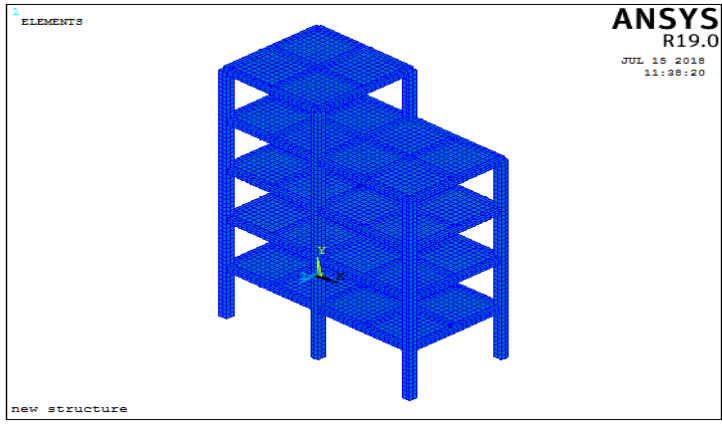

Fig 2. 3D model of the building with bracing and without bracing for fixed base

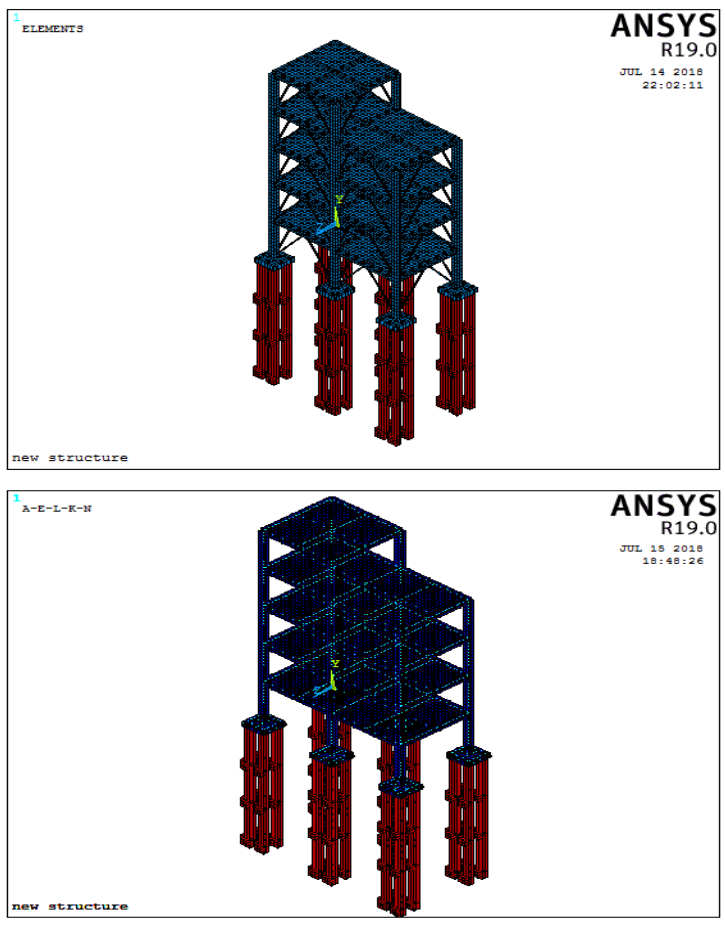

Fig 3. 3D model of the building with bracing and without bracing for flexible base.
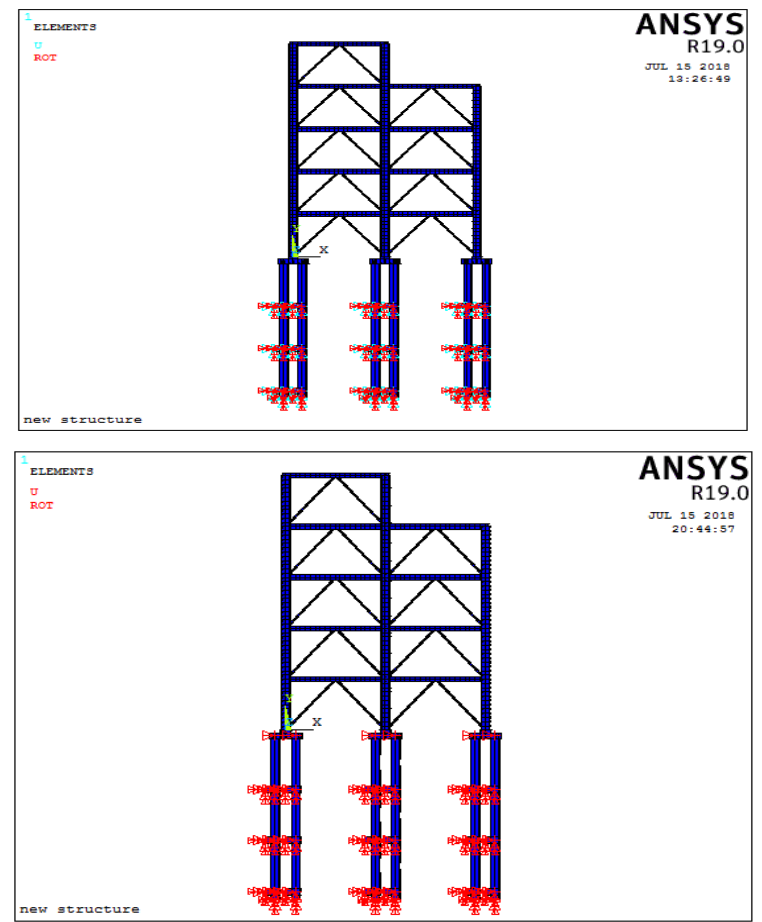

Fig 4 3D model for Free headed and fixed headed pile condition

\section{RESULTS AND DISCUSSIONS}

The analysis using ANSYS v19 has been performed for various combination of soil profile under free head and fixed head pile condition with and without bracing using Winkler model. The horizontal displacement and storey drift, bending moment along the pile and time period at different storey level were obtained and the results are tabulated for different combination as shown below.

\section{A. Fixed base analysis}

Table 4: Displacement values at different levels for a fixed base RC building

\begin{tabular}{|c|c|c|c|c|}
\hline \multirow{2}{*}{$\begin{array}{c}\text { STOREY } \\
\text { HEIGHT } \\
(\mathbf{M})\end{array}$} & \multicolumn{4}{|c|}{ DISPLACEMENT (MM) } \\
\cline { 2 - 5 } & \multicolumn{4}{|c|}{ Combination-I } \\
\cline { 2 - 5 } & FREE & FIXED & HEADED \\
\hline 15 & HEADED & HEADED & HEADED & 152.6 \\
\hline 12 & 45.94 & 176.19 & 18.1 & 135.99 \\
\hline 9 & 42.14 & 161.58 & 14.8 & 110.74 \\
\hline 6 & 38.31 & 138.71 & 11.53 & 75.71 \\
\hline 3 & 29.46 & 106.25 & 7.9 & 35.33 \\
\hline 0 & 20.32 & 66.36 & 4.1 & 0.82 \\
\hline-3 & 5.1 & 22.66 & 0.17 & 0.79 \\
\hline-6 & 0.91 & 0.97 & 0.06 & 0.12 \\
\hline-9 & 0.5 & 0.21 & 0.02 & 0.04 \\
\hline
\end{tabular}

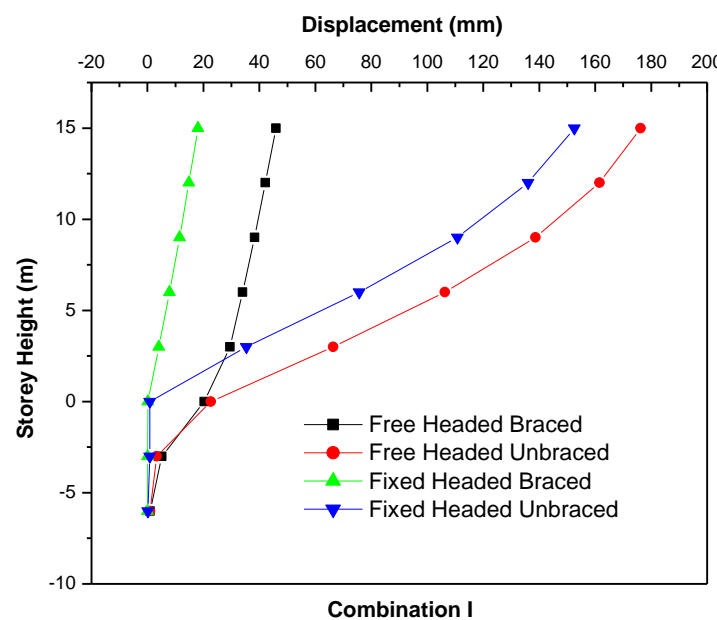

Fig: 5: Displacement v/s storey height

Table 5: Displacement values at different levels for Combination II

\begin{tabular}{|c|c|c|c|c|}
\hline \multirow{2}{*}{$\begin{array}{c}\text { STOREY } \\
\text { HEIGHT } \\
(\mathbf{M})\end{array}$} & \multicolumn{4}{|c|}{ DISPLACEMENT (MM) } \\
\cline { 2 - 5 } & & FIXED & FIXED \\
& FREE & HEADED & FEADEE & HEADED \\
\cline { 2 - 5 } & HEADED & HEADED & 152.6 \\
\hline 15 & 45.94 & 176.19 & 18.1 & 135.99 \\
\hline 12 & 42.14 & 161.58 & 14.8 & \\
\hline
\end{tabular}


Seismic Response of Steel Braced Vertically Irregular RC Frame Considering Soil Structure Interaction

\begin{tabular}{|c|c|c|c|c|}
9 & 38.31 & 138.71 & 11.53 & 110.74 \\
\hline 6 & 34.04 & 106.25 & 7.9 & 75.71 \\
\hline 3 & 29.46 & 66.36 & 4.1 & 35.33 \\
\hline 0 & 20.32 & 22.66 & 0.17 & 0.82 \\
\hline-3 & 5.1 & 3.26 & 0.09 & 0.79 \\
\hline-6 & 0.91 & 0.97 & 0.06 & 0.12 \\
\hline-9 & 0.5 & 0.21 & 0.02 & 0.04 \\
\hline
\end{tabular}

From figure 5 and 6, it can be concluded that the horizontal displacement of a 4 storey vertically irregular RC building when SSI was considered with the pile tip resting on saturated loose sand in combination I and on stiff clay in combination II, showed maximum displacement values when resting on saturated sand than in the stiff clay. Overall free head structure has more displacement compared to the fixed head structures.

Table 6: Storey Drift values at different levels for Combination -I

\begin{tabular}{|c|c|c|c|c|}
\hline \multirow{3}{*}{$\begin{array}{l}\text { STOREY } \\
\text { HEIGHT }\end{array}$} & \multicolumn{4}{|c|}{ STOREY DRIFT } \\
\cline { 2 - 5 }$(\mathbf{M})$ & \multicolumn{4}{|c|}{ Combination -I } \\
\cline { 2 - 5 } & FREE & \multicolumn{4}{|c|}{$\begin{array}{l}\text { FIXED } \\
\text { HEADED }\end{array}$} & $\begin{array}{l}\text { FREE } \\
\text { HEADED }\end{array}$ & $\begin{array}{c}\text { FIXED } \\
\text { HEADED }\end{array}$ \\
\hline 5 & 3.8 & 14.61 & 3.3 & 16.61 \\
\hline 4 & 3.83 & 22.87 & 3.27 & 25.25 \\
\hline 3 & 4.27 & 32.46 & 3.64 & 35.02 \\
\hline 2 & 4.58 & 39.89 & 3.79 & 40.39 \\
\hline 1 & 9.14 & 43.7 & 3.93 & 34.5 \\
\hline 0 & 20.32 & 22.66 & 0.1726 & 0.8287 \\
\hline
\end{tabular}

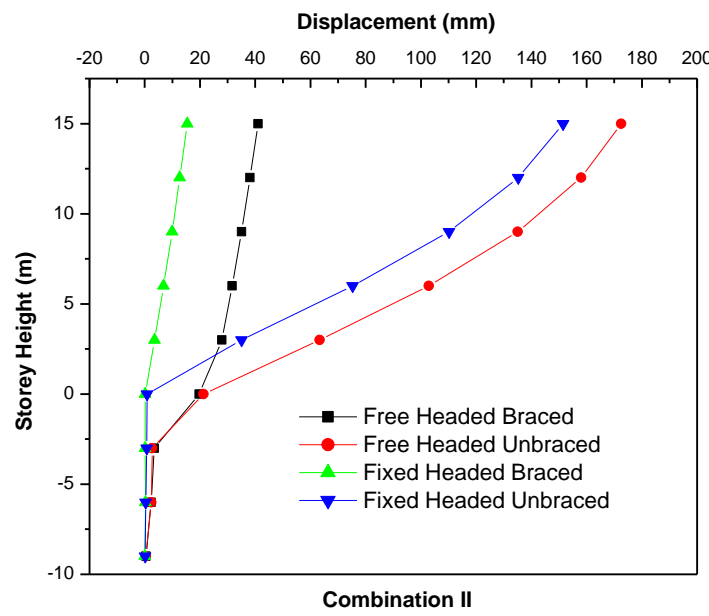

Fig: 6: Displacement v/s storey height

Table 7: Storey Drift values at different levels for Combination-II

\begin{tabular}{|c|c|c|c|c|}
\hline \multirow{3}{*}{$\begin{array}{l}\text { STOREY } \\
\text { HEIGHT } \\
\text { (M) }\end{array}$} & \multicolumn{4}{|c|}{ STOREY DRIFT } \\
\hline & \multicolumn{4}{|c|}{ Combination -I } \\
\hline & $\begin{array}{l}\text { FREE } \\
\text { HEADED }\end{array}$ & $\begin{array}{l}\text { FIXED } \\
\text { HEADED }\end{array}$ & $\begin{array}{l}\text { FREE } \\
\text { HEADED }\end{array}$ & $\begin{array}{c}\text { FIXED } \\
\text { HEADED }\end{array}$ \\
\hline 5 & 3.8 & 14.61 & 3.3 & 16.61 \\
\hline 4 & 3.83 & 22.87 & 3.27 & 25.25 \\
\hline 3 & 4.27 & 32.46 & 3.64 & 35.02 \\
\hline 2 & 4.58 & 39.89 & 3.79 & 40.39 \\
\hline 1 & 9.14 & 43.7 & 3.93 & 34.5 \\
\hline 0 & 20.32 & 22.66 & 0.1726 & 0.8287 \\
\hline
\end{tabular}

\begin{tabular}{|c|c|c|c|c|}
\hline \multirow{3}{*}{$\begin{array}{l}\text { STOREY } \\
\text { HEIGHT }\end{array}$} & \multicolumn{4}{|c|}{ STOREY DRIFT } \\
\cline { 2 - 5 } & \multicolumn{4}{|c|}{ Combination -II } \\
\cline { 2 - 5 } & FREE & \multicolumn{4}{|c|}{} & $\begin{array}{l}\text { FIXED } \\
\text { HEAD } \\
\text { ED }\end{array}$ \\
\hline 5 & 2.94 & 14.49 & 2.73 & 16.25 \\
\hline 4 & 2.97 & 23 & 2.72 & 25.03 \\
\hline 3 & 3.44 & 32.14 & 3.09 & 34.88 \\
\hline 2 & 3.74 & 39.6 & 3.26 & 40.27 \\
\hline 1 & 8.22 & 42.05 & 3.41 & 34.24 \\
\hline 0 & 19.7 & 21.264 & 0.162 & 0.8047 \\
\hline
\end{tabular}

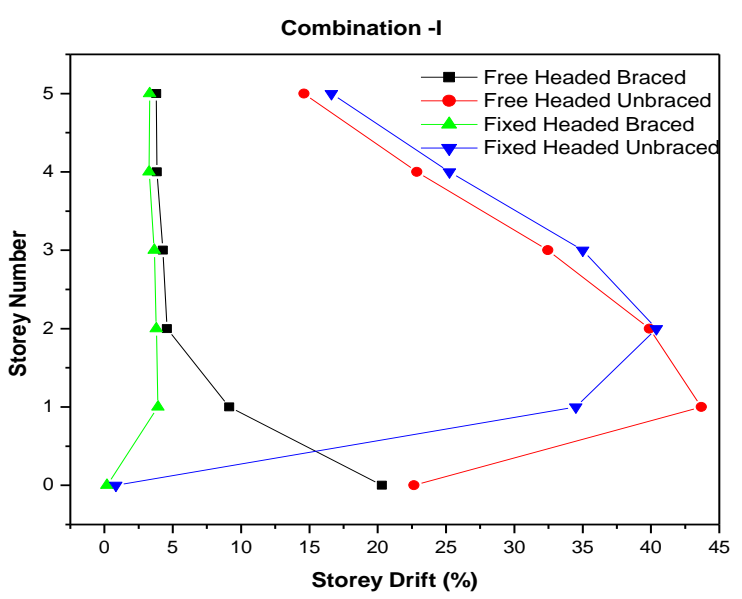

Fig: 7: Storey Drift v/s storey Number

Table 8: Bending Moment values along the pile length for combination-I

\begin{tabular}{|c|c|c|c|c|}
\hline \multirow{2}{*}{$\begin{array}{l}\text { Pile } \\
\text { Length } \\
(\mathbf{m})\end{array}$} & \multicolumn{4}{|c|}{ BENDING MOMENT ALONG THE PILE (KN-M) } \\
\cline { 2 - 5 } & \multicolumn{4}{|c|}{ COMBINATION-I } \\
\cline { 2 - 5 } & $\begin{array}{c}\text { FREE } \\
\text { HEADED }\end{array}$ & $\begin{array}{c}\text { FIXED } \\
\text { HEADED }\end{array}$ & $\begin{array}{c}\text { FREE } \\
\text { HEADED }\end{array}$ & $\begin{array}{c}\text { FIXED } \\
\text { HEADED }\end{array}$ \\
\hline 0 & 38.8 & 71.51 & 7.95 & 34.12 \\
\hline-3 & 67.06 & 67.57 & 3.489 & 10.21 \\
\hline-6 & 3.42 & 3.8 & 1.09 & 1.33 \\
\hline-9 & 3.42 & 3.8 & 1.08 & 1.32 \\
\hline
\end{tabular}

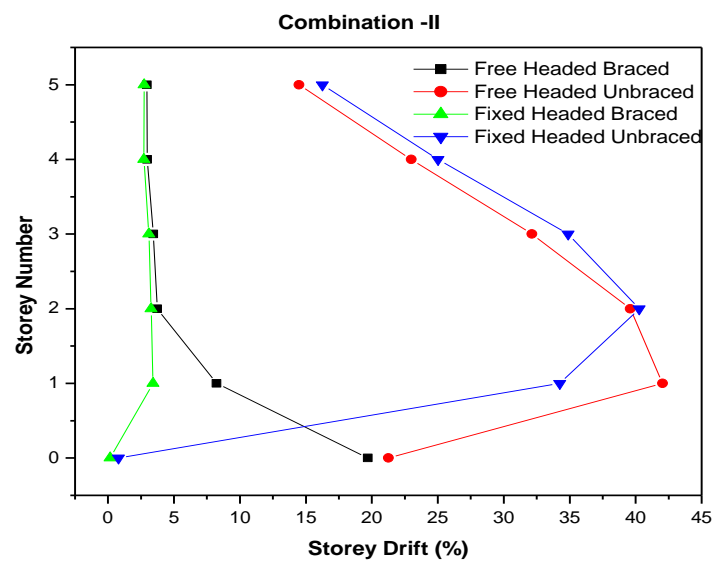

Fig: 8: Storey Drift v/s Storey number

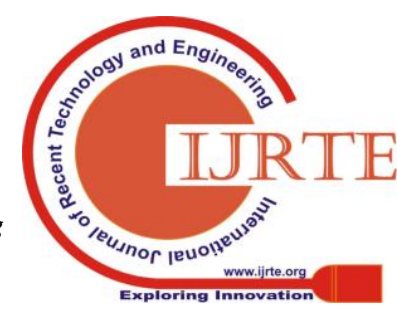


From the figure 7 and 8, it can be concluded that the storey drift for the unbraced structure for both free head and fixed head was maximum in the middle stories, where the drift seen in combination I soil was slightly more than the drift in combination II. Wherein the braced structure fixed head condition on combination I showed lesser drift compared to the free head braced structure.

Table 9: Bending Moment values along the pile length for combination -II

\begin{tabular}{|c|c|c|c|c|}
\hline \multirow{2}{*}{$\begin{array}{l}\text { Pile } \\
\text { Length }\end{array}$} & \multicolumn{4}{|c|}{ BENDING MOMENT ALONG THE PILE (KN-M) } \\
\cline { 2 - 5 } & \multicolumn{4}{|c|}{ COMBINATION-II } \\
\cline { 2 - 5 } & $\begin{array}{c}\text { FREE } \\
\text { HEADED }\end{array}$ & $\begin{array}{c}\text { FIXED } \\
\text { HEADED }\end{array}$ & $\begin{array}{c}\text { FREE } \\
\text { HEADED }\end{array}$ & $\begin{array}{c}\text { FIXED } \\
\text { HEADED }\end{array}$ \\
\hline 0 & 23.78 & 51.2 & 7.38 & 31.9 \\
\hline-3 & 78.4 & 74.31 & 1.8 & 9.29 \\
\hline-6 & 14.33 & 13.8 & 2.33 & 4.02 \\
\hline-9 & 14.105 & 11.01 & 2.08 & 3.57 \\
\hline
\end{tabular}

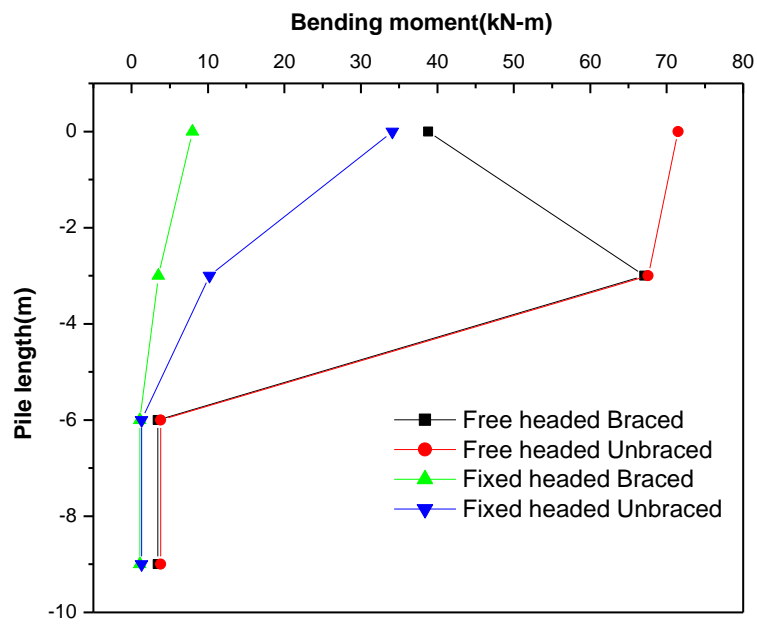

Combination -

Fig: 9: Bending Moment v/s Pile length

From figure 9 and 10, it can be concluded that the bending moment along the pile head was maximum in unbraced free and fixed headed structure, where the bending moment was slightly higher when the piles were resting on saturated soil in combination I than while resting on combination II. The bending moment was seen larger at the pile head and decreases along the pile tip. Free head structure shows higher bending moment compared to the fixed head structure.

Table 10: Time period values at different modes for fixed base analysis

\begin{tabular}{|c|c|}
\hline \multicolumn{2}{|c|}{ Time period Values for First Six modes } \\
\hline BRACED & UNBRACED \\
\hline 0.190 & 0.730 \\
\hline 0.154 & 0.690 \\
\hline 0.119 & 0.510 \\
\hline 0.067 & 0.222 \\
\hline 0.060 & 0.217 \\
\hline 0.058 & 0.156 \\
\hline
\end{tabular}

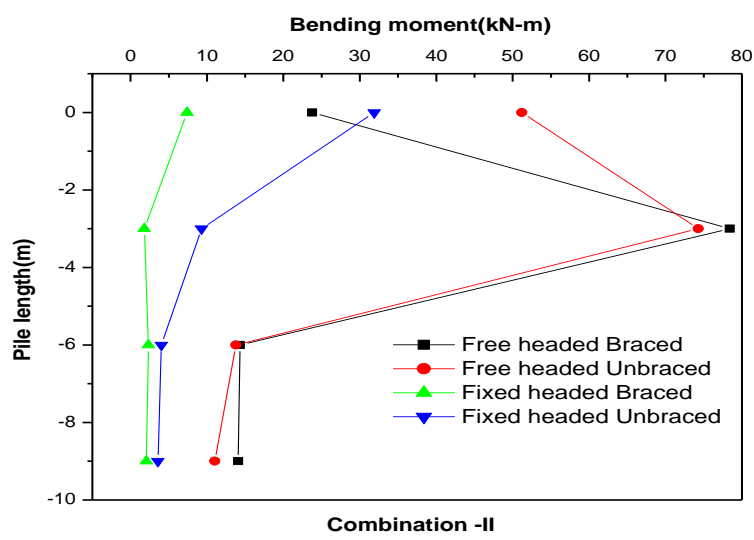

Fig: 10: Bending Moment v/s Pile length

From figure 11 and 12, it can be concluded that the time period response of the free head and fixed headed structure increases considering soil structure interaction when compared with fixed base structure without considering the soil structure interaction. The time period for combination II is slightly less compared to combination I . Hence it can be concluded that the difference in time periods for different soils decreases as we move from saturated soil to hard stiff soils.

Table 11: Time period values at different modes.

\begin{tabular}{|c|c|c|c|c|}
\hline \multirow{3}{*}{\begin{tabular}{c}
\multirow{3}{*}{$\begin{array}{c}\text { MODE } \\
\text { NO }\end{array}$} \\
\cline { 2 - 5 }
\end{tabular}} & \multicolumn{4}{|c|}{ TIME PERIOD (sec) FOR 6 FUNDAMENTAL } \\
MODE NUMBERS \\
\cline { 2 - 5 } & FREE & FIXED & FREE & FIXED \\
HEADED & HEADED & HEADED & HEADED \\
\hline 1 & 0.473 & 0.936 & 0.348 & 0.819 \\
\hline 2 & 0.4 & 0.878 & 0.245 & 0.759 \\
\hline 3 & 0.28 & 0.652 & 0.13 & 0.559 \\
\hline 4 & 0.14 & 0.282 & 0.104 & 0.241 \\
\hline 5 & 0.128 & 0.272 & 0.071 & 0.234 \\
\hline 6 & 0.109 & 0.202 & 0.067 & 0.17 \\
\hline
\end{tabular}

Table 12: Time period values at different modes

\begin{tabular}{|c|c|c|c|c|}
\hline \multirow{3}{*}{$\begin{array}{c}\text { MODE } \\
\text { NO }\end{array}$} & \multicolumn{4}{|c|}{$\begin{array}{c}\text { TIME PERIOD (sec) FOR } 6 \text { FUNDAMENTAL } \\
\text { MODE NUMBERS }\end{array}$} \\
\hline & \multicolumn{4}{|c|}{ COMBINATION-II } \\
\hline & $\begin{array}{l}\text { FREE } \\
\text { HEADED }\end{array}$ & $\begin{array}{l}\text { FIXED } \\
\text { HEADED }\end{array}$ & $\begin{array}{l}\text { FREE } \\
\text { HEADED }\end{array}$ & $\begin{array}{l}\text { FIXED } \\
\text { HEADED }\end{array}$ \\
\hline 1 & 0.44 & 0.914 & 0.31 & 0.8 \\
\hline 2 & 0.383 & 0.861 & 0.22 & 0.754 \\
\hline 3 & 0.279 & 0.64 & 0.13 & 0.557 \\
\hline 4 & 0.138 & 0.278 & 0.091 & 0.24 \\
\hline 5 & 0.117 & 0.269 & 0.07 & 0.234 \\
\hline 6 & 0.09 & 0.2 & 0.066 & 0.169 \\
\hline
\end{tabular}




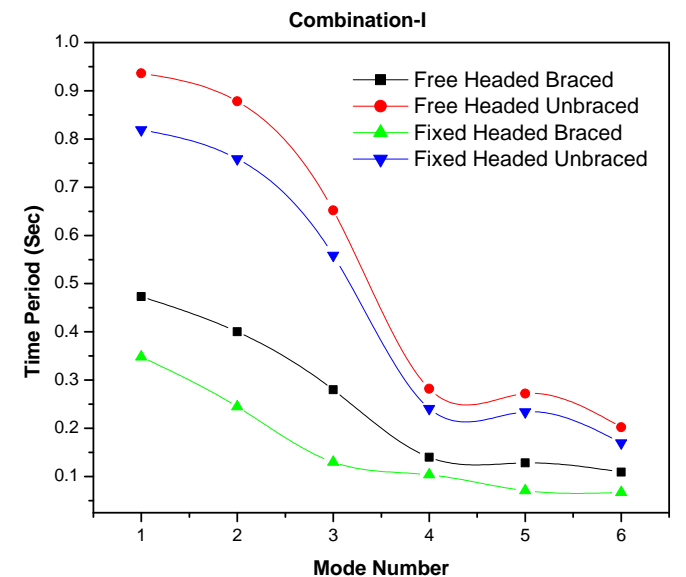

Fig: 11: Time Period v/s Mode number

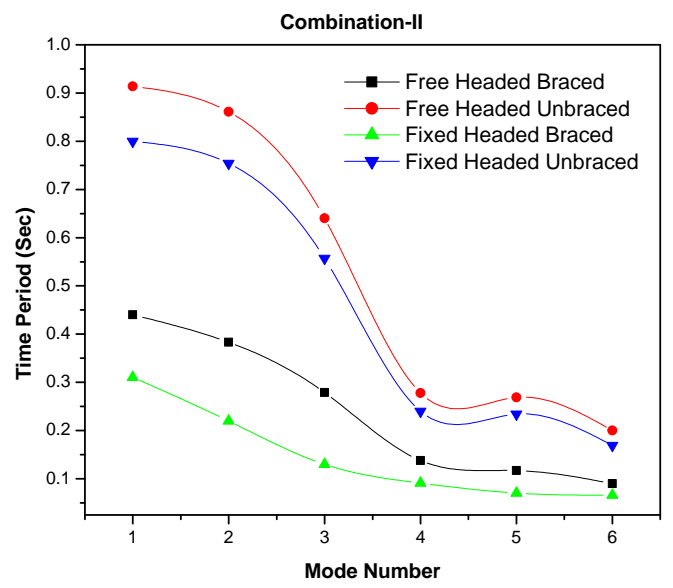

Fig: 12: Time Period v/s Mode number

\section{CONCLUSION}

Based on the response spectrum analysis and observations made during the present investigation the following conclusions were drawn;

1. Increase in the stiffness of the soil resulted in the decrease in displacement of the structure for the two combination of the soil profile i. e, piles resting on saturated soil shows maximum displacement compared to piles resting on stiff clay.

2. The displacement for the free headed and fixed headed structures considering SSI compared with the fixed base structure without considering SSI, showed relatively high displacement values when SSI was considered.

3. Fixed headed structure showed less horizontal displacement compared to free headed structure

4. Storey drift for the unbraced structure for both free head and fixed head was maximum in the middle stories.

5. Bending moment along the pile was higher near the pile head for the unbraced structure for both free and fixed headed condition and also it has slightly higher values when pile is resting on saturated soil when compared to unsaturated stiff soil.

6. Time period of all the structures increases when soil structure interaction effects is considered when compared with fixed base structure without considering SSI effects. The difference in the time period decreases as we move from soft soils to hard soils.

\section{ACKNOWLEDGMENT}

We sincerely thank management, CE, Principal and Head of Department of Ramaiah Institute of Technology, Bangalore -560054, affiliated to VTU, Belgaum for all the technical guidance.

\section{REFERENCES}

1. Gu Q.(2008), "Finite Element. Response Sensitivity and Reliability Analysis of Soil-Foundation-Structure-Interaction (SFSI) Systems". University of California ,San Diego

2. Chopra AK, Gutierrez JA.(1974) Earthquake response analysis of multistory buildings including foundation interaction. Earthquake Engineering Structure Dynamics.

3. Soni DP and Mistry BB (2006) Qualitative review of seismic response of vertically irregular building frames, ISET Journal of Earthquake technology, Technical note, 43(4): 121-132.

4. Kotkar R.K, Patankar J P.(2017), "Effect of Soil structure interaction on buildings with stiffness irregularity under seismic load" International research journal of engineering and technology.

5. Thusoo,s., Modi,K., Kumar,R., \& Madahar,H.(2015). Response of buildings with soil structure interaction with varying soil types. World Academy of Science, Engineering and Technology, International Journal of civil , Envirnomental, Structural , Construction and Architectural Engineering , 9(4).414-418.

6. Bureau of Indian standards (IS 1893),. (2002). Part I: Criteria for Earthquake resistant Design of Structures: General Provisions and Buildings.

7. Bureau of Indian standards (IS 2911),. (2002). Part I sec 3 : Criteria for Design and Construction of Pile Foundations.

\section{AUTHORS PROFILE}

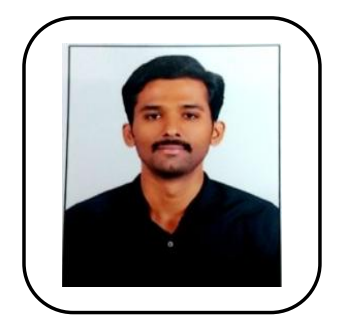

Basavanagowda $\mathbf{G} \mathbf{M}$ is currently working as Assistant Professor in Department of Civil Engineering,, RIT, Bangalore..He has total teaching experience of 10 years. His area of specialization is soil dynamics and Earthquake Engineering. He is a life member of ISTE.

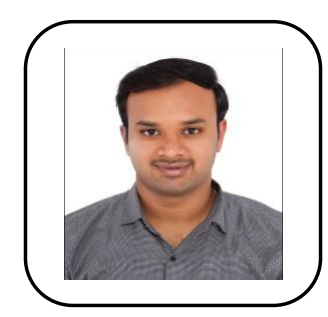

Raje Gowda is currently working as Assistant professor in Department of Civil Engineering RIT, Bangalore. He has total teaching experience of 6 years. His area of specialization is concrete and nano-structured materials.

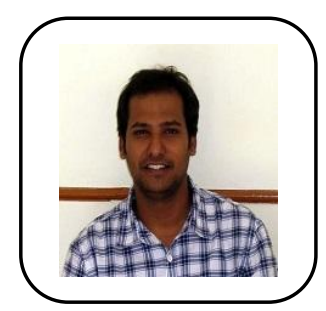

ICI, ISTE.
Mr. Prashant Sunagar is working as Assistant professor in Civil engineering department at Ramaiah Institute of Technology Bangalore. He holds a M.Tech degree in structural engineering from VTU, Belagavi. Presently he is pursuing $\mathrm{Ph} \mathrm{D}$ in the field of Structural Engineering from VTU, Belagavi. His areas of interests include structural stability, Concrete technology, earthquake engineering. He is life member of 


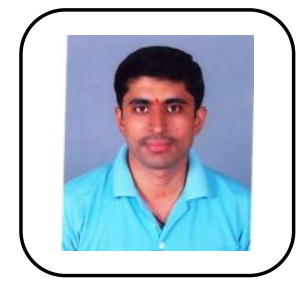

Mr. Manish S Dharek is working as Assistant professor in Civil engineering department at BMS Institute of Technology and Management, Bangalore. He holds M.Tech degree in Construction technology from VTU, Belagavi. He has been awarded gold medal and first rank in the convocation during 2011.Presently he is pursuing Ph.D in the field of Earthquake Engineering from VTU, Belagavi. His areas of interest include structural masonry, alternative building materials, GIS. He is a life member of ICI, NICEE, and SEFI 